\title{
Experimental ceramic proppants characterization in the process of shale gas extraction
}

\author{
Charakterystyka eksperymentalnych propantów ceramicznych \\ służących w procesie pozyskiwania gazu z łupków
}

\author{
MARCIN MAŁEK \\ PAWEK WIŚNIEWSKI \\ MATEUSZ KONRAD KORALNIK \\ JOANNA SZYMAŃSKA \\ JAROS $Ł A W$ MIZERA \\ KRZYSZTOF JAN KURZYDŁOWSKI *
}

\author{
DOI: 10.17814/mechanik.2016.5-6.64 \\ Międzynarodowa Konferencja IMT 2016
}

\begin{abstract}
The presented paper relates to the application of new experimental proppants in the process of shale gas extraction. The tested proppants were produced through mechanical granulation methods. Ceramic proppants were sintered at $1550{ }^{\circ} \mathrm{C}$. The characterization of investigated proppants was carried out using Scanning Electron Microscope (SEM) and Light Microscope (LM). Properties of ceramic proppants such as: bulk density, crash tests, moisture, solubility in acids, sphericity factor, turbidity were studied using a range of techniques. The results show that new experimental proppants meet the industrial requirements and need some modification for future application.
\end{abstract}

KEYWORDS: ceramic proppants, mechanical granulation, shale gas

Artykuł przedstawia wyniki badań eksperymentalnych propantów ceramicznych z przeznaczeniem do wydobywania gazu z łupków. Otrzymane propanty zostały poddane spiekaniu $w$ temperaturze $1550^{\circ} \mathrm{C}$. Otrzymane w ten sposób próbki poddano badaniom mikrostruktury SEM, gęstości nasypowej, wytrzymałości mechanicznej, wilgotności, odporności na kwasy, współczynnika kulistości oraz mętności, z użyciem przeznaczonych do tych badań technik. Stwierdzono, iż nowo uzyskane propanty spełniają założenia przemysłowe, jednak wymagają modyfikacji w celu zastosowania ich do wydobywania gazu z formacji łupkowych.

SŁOWA KLUCZOWE: propanty ceramiczne, granulowanie mechaniczne, gaz łupkowy

The growing energy demand forces to discover and develop new technology and beds for energy production in the word. In past, when unconventional deposits of shale gas where discovered for the first time, its extraction from shale rock had a marginal share in the natural gas processing $[1 \div 3]$.

For economic reasons and the lack of techniques for exploitation of the new beds, shale gas plays a small role in energy industry. Today, through a better understanding of mining technology and beds geological identification, new energy sources are very desirable in the energy market.

\footnotetext{
* Mgr inż. Marcin Małek (marcin.malek@wimpw.edu.pl), dr inż. Paweł Wiśniewski (p.wisniewski@inmat.pw.edu.pl), mgr inż. Mateusz Konrad Koralnik (mateusz.koralnik@gmail.com), mgr inż. Joanna Szymańska (joanna.szymanska.pl@gmail.com), prof. nadzw. dr hab. inż. Jarosław Mizera (jmizera@inmat.pw.edu.pl), prof. zw. dr hab. inż. Krzysztof Jan Kurzydłowski (kjk@inmat.pw. edu.pl) - Wydział Inżynierii Materiałowej, Politechnika Warszawska
}

For various reasons the extraction of shale gas from Polish beds is very difficult. One of very important causes is the location of beds. Polish shale gas is located very deeply in the ground. Depth reaches up to $3 \mathrm{~km}$. Therefore acquisition of shall gas is very expensive. The light weight ceramic proppant can provide a solution for this problem. This specific materials can be applied in hydraulic fracturing method. They are characterized by spherical shape and are increasingly used for extraction of shale gas from beds in US by injecting them to boreholes. These granulates pumped with liquid into the deposit cause destruction of rock with shale gas. Due to this process, proppants must exhibit suitable physico-mechanical properties $[1,4 \div 6]$.

\section{Methodology}

This research was conducted utilizing new ceramic proppant sintered in $1550{ }^{\circ} \mathrm{C}$ and based on Polish raw materials. To characterize microstructure, Hitachi SU-70 with $10 \mathrm{kV}$ voltage and YAGBSE detector was used. Evaluation of particle shape was measured using MicroMeter 1.04 software, and ceramic proppants pictures taken on Nikon DS-F12. Turbidity measurements were made using a TurbiDirect_4a, wherein the beam of light is perpendicular to the detector. The volume of measured sample was $20 \mathrm{ml}$. To study the solubility in acids, $\mathrm{HCl}: \mathrm{HF}$ acids with the ratio $12: 3$ were used. Bulk density and crash tests were performed according to Polish Standard PN-EN ISO 13503-2. Moisture analysis was conducted in RadWag moisture analyzer.

\section{Results and Discussion}

Fig. 1 shows SEM and LM images of investigated ceramic proppant. It was fabricated using Polish raw materials in granulation method. Images present large proppant particle with the shape similar to the sphere. Many different particle sizes of investigated proppant were observed in LM image (Fig. 1c). EDS results of characterized proppant showed, that the main components are aluminium and silicon oxides (Fig. 1b).

To measure the average equivalent diameter $(0.89 \mathrm{~mm})$, one of the Nikon DS-F12 photos (Fig. 2) was used. The sphericity of studied proppant is 0.84 .

Basic properties of studied proppant were characterized in Tab. I. Investigated proppant exhibits adequate properties which are within the range of values accepted by the industry.

Fig. 3 and Tab. II summarize the crash tests results. Tests speed of the piston was $1 \mathrm{~mm} / \mathrm{min}$. Holding matrix time was $2 \mathrm{~min}$. For the first sample, the pressure of $50 \mathrm{MPa}$ 
was used, for the second one $-75 \mathrm{MPa}$ and for the third one - $100 \mathrm{MPa}$. For these pressures, samples exhibit the strain values of $105 \mathrm{kN}, 142 \mathrm{kN}, 181 \mathrm{kN}$, respectively.

a)

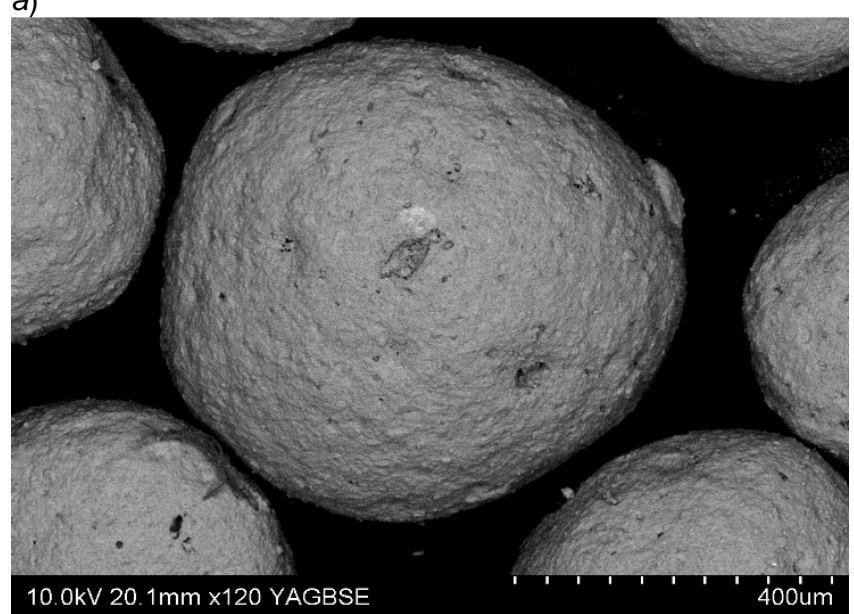

b)

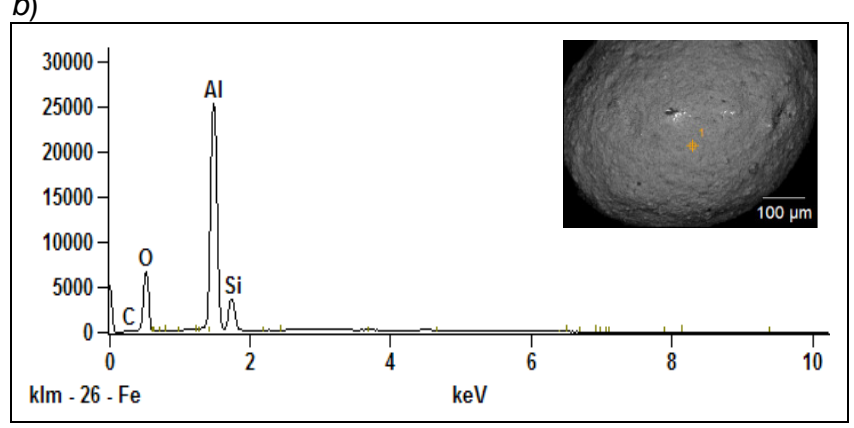

c)

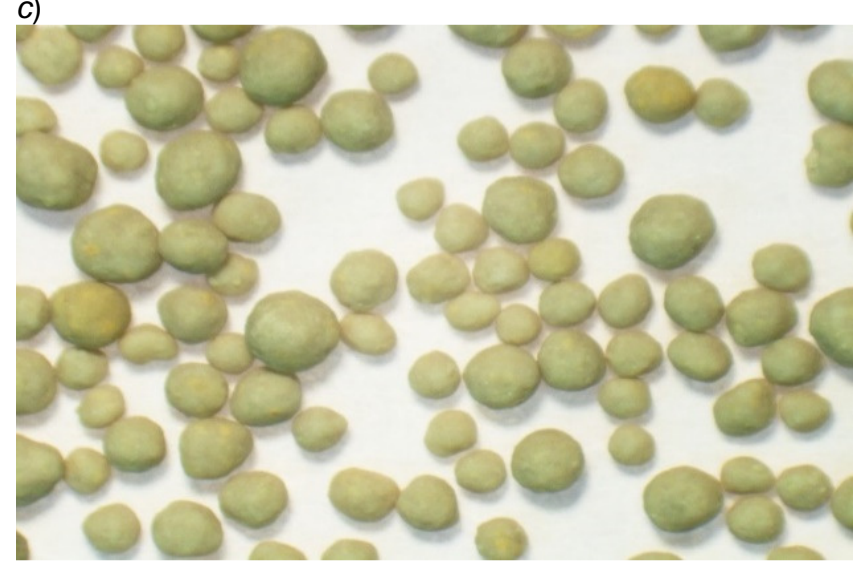

Fig. 1. SEM and LM images of investigated proppants: a) SEM images, $b$ ) EDS results, c) LM images

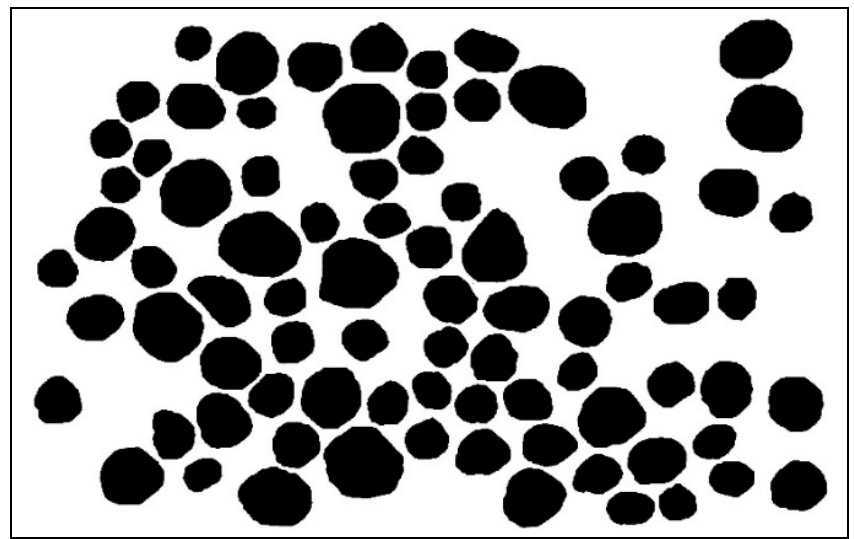

Fig. 2. LM image of investigated proppants used to measure equivalent diameter and sphericity factor
TABLE I. Basic properties of investigated proppants

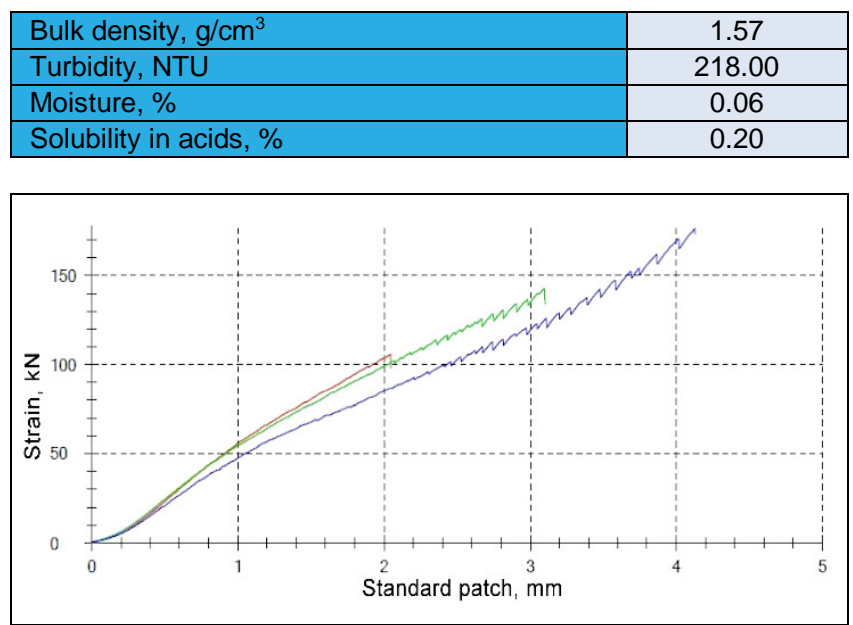

Fig. 3. Crash test results for investigated proppants

TABLE II. Crash tests parameters

\begin{tabular}{|l|c|c|}
\hline Sample No. & Strain, $\mathrm{kN}$ & Standard path, $\mathrm{mm}$ \\
\hline 1$)$ & 105 & 2.05 \\
\hline 2$)$ & 142 & 3.12 \\
\hline 3$)$ & 181 & 4.17 \\
\hline
\end{tabular}

\section{Summary}

Experimental ceramic proppants obtained by mechanical granulation method are characterized by appropriate parameters, i.e. low bulk density, solubility in acid and a relatively high value of sphericity-0.84. These granules provide the basis for application in the hydraulic fracturing process.

However, obtained proppants did not exhibit very high strength. The amounts of destroyed granules were: for $7500 \mathrm{psi}-5.5 \%$, for $10000 \mathrm{psi}-21 \%$ and for $15000 \mathrm{psi}-$ over $30 \%$. These values are unacceptable by the industry. Additionally, researched proppants revealed too high value of turbidity, therefore they need further refinement for future application.

Financial support of BLUE GAS is financed from The National Centre for Research and Development - Project "Optimizing the lightweight high strength and low specific gravity ceramic proppants production technology maximally using naturally occurring Polish raw materials and fly ash", No. BG1/BALTICPROPP/13 is gratefully acknowledged.

\section{LITERATURE}

1. Gaurav A., Dao E. K., Mohanty K. K, „Evaluation of ultra-lightweight proppants for shale fracturing”. Journal of Petroleum Science and Engineering. Vol. 92-93 (2012), pp. 82 $\div 88$.

2. Reinicke A., Rybacki E., Stanchits S., Huenges E., Dresen G., „Hydraulic fracturing stimulation techniques and formation damage mechanisms - Implications from laboratory testing of tight sandstone-proppant systems". Chemie der Erde - Geochemistry.

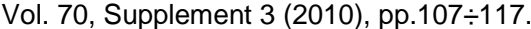

3. Wu T., Wu B., Zhao S. „Acid resistance of silicon-free ceramic proppant". Materials Letters. Vol. 92 (2013): pp.210 $\div 212$.

4. Kulkarni M., Ochoa O.O., „Mechanics of light weight proppants: A discrete approach". Composites Science and Technology. Vol.

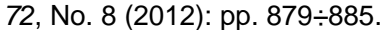

5. Strizhakova Yu. A., Usova T. V., „Environmental Problems of Oil Shale Processing Industry”. Solid Fuel Chemistry. Vol. 41, No. 3 (2007): pp. $174 \div 178$

6. Małek M., Wiśniewski P., Koralnik M., Szymańska J., Zarzycka D., Mizera J., Kurzydłowski K.J., „Study of deflocculation of white clay for obtaining ceramic proppants fabrication in spray dryer". Archives of Materials Science and Engineering. Vol 75, No. 2

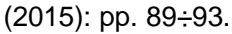

